\title{
COMMUNITY EVALUATION ON THE EFFECTS OF TOURISM IN DOOT POKTOY, LANUZA
}

\author{
Mariae Khrisna B. Arreza \\ Cebu Institute of Technology- University; Cebu Normal University \\ mariae_arreza@outlook.com; arrezamk@cnu.edu.ph
}

\begin{abstract}
Doot Poktoy is an emerging surfing destination in Mindanao. In developing tourism, Policymakers could aim for long-term tourism growth. Sustainable tourism is intensely dependent on the host community's support, view, and contribution to tourism programs; this safeguards the community and diminishes any adverse effects that can harm the environment and culture. However, literature is scarce about comparing the positive and negative effects of tourism. Thus, this paper focuses on the following objectives: Determine the positive and negative effects of tourism and; Test the significant difference between the positive and negative responses. The study gathered 93 responses from Doot Poktoy residents'. It utilized the descriptive approach, with questionnaires indicating the agreement level in the values of tourism development: economic, socio-cultural, and environmental. The results revealed that the respondents had experienced both negative and positive effects of tourism and that they have a more negative view of tourism than a positive one.
\end{abstract}

Keywords: Tourism development; Tourism effects; Community evaluation

\section{INTRODUCTION}

The Pacific Ocean captures the curiosity of local and foreign surfers because of its dimension and length. Lanuza, a small municipality in Surigao del Sur, faces the Pacific Ocean, making it one of the top surfing spots in the Philippines. It is not yet popular, but the waves in Lanuza are equal to Siargao or La Union. The surfing spot in Lanuza is at the gateway of Doot Poktoy River, a surfing haven for both locals and tourists. The surfing spot is distinguished for its right-hander waves and is considered as longest in the Philippines (Manila Standard, 2017).

The Local Government of Lanuza sees an opportunity to conduct local, national, and international surfing events and aspires to make Lanuza the surfing retreat and sports adventure tourism destination in the Caraga region. The tourism activities created by the Local Government led to feature the development of other natural and cultural attractions of the municipality, such as (a) Lanuza Marine Park Sanctuary where sea turtles and leatherback turtles are frequent, (b) Magkawas Falls, (c) Campamento Cave, and (d) the century-old Herrera Ancestral House (Manila Standard, 2017). Lanuza's diverse tourist spots are perfect for an adventure and ecotourism escape for those tourists who seek it. The surfing events, organized 
through a private-public partnership, cover activities that promote local trade fairs, initiate coastal cleanups, show music performances, conduct surfing clinics, and hold local pageants. The success of the surfing tourism activities increased the number of tourists by the year, making Lanuza the new surfing retreat of Mindanao.

The success of Lanuza shows that tourism can be a way for community development. This is also evident in some developing countries that chose tourism as their way to advancement and progress. There are developing countries that have chosen tourism as their advance to progress. Several developed countries have established tourism as a fast chance of achieving revenue, and tourism has become a contender to other enterprises such as agriculture (Khan, Bibi, Lorenzo, Lyu, \& Babar, 2020). Most of these developing countries are mainly underprivileged and practically in debt and deprived of prior understanding of the tourism industry's complexity.

Tourism infrastructure expansions depend profoundly on external funds. These investments are prone to deplete the national economy and the local community resources. Hence, the developing countries long for positive economic benefits; tourism is frequently one of the varied advancement routes and a favored option for both developed and developing nations. Tourism is an economic development track for the operationally weak and marginal areas. It is sometimes viewed as a panacea that provides economic sovereignty to local people. Moreover, it provides occupations and revenue, capital inflow, and creates a progressive socioeconomic prospect. Usually, the countries that rely heavily on tourism tend to be oblivious to the fact that tourism may also produce negative economic, sociocultural, and environmental effects (Ardahaey, 2011; Liu et al., 2012; Marius \& Luisa, 2016; Mason, 2003; Mikayilov, Mukhtarov, Mammadov, \& Azizov, 2019; Zaei \& Zaei, 2013).

It is essential that the development of tourism has to be treated with great care and management. A sustainable method should be pondered for tourism development (Pramanik \& Ingkadijaya, 2018; Spilanis, Vayanni, \& Glyptou, 2013). Any national government must plan for long-term progress; it is necessary to conduct sustainable tourism development to reduce its negative impacts. The effects of tourism in a community can be positive or valuable, but also negative or harmful. Whether the effects are seen as positive or negative varies on the opinion and values of the person. There are three kinds of tourism impacts that would affect the community and the environment: economic, socio-cultural, and environmental. The effects of ecotourism in a society depend on the opinions or values of the people based on its economic, socio-cultural, or environmental impacts (Butarbutar \& Soemarno, 2013; Mason, 2003).

Ecotourism incorporates the environment, economy, and local communities through these three elements: (a) the conservation aspects of tourism activities, help local conservation and preservation efforts with the least manifestation of unfavorable effects; (b) the educational component, specifically the tourists visiting the destination, will learn about ecotourism and the destinations' distinctive local biological and socio-cultural values; and (c) the social aspect, the participation of the local people who have vital roles in implementing any tourism activities. The government plan needs to empower the communities economically by providing a part in ecotourism for local communities and increasing their contribution to environmental and cultural conservation and preservation (Butarbutar \& Soemarno, 
2013). Whether tourism is widespread or small, tourism is an essential measure that can impact the local community. This is predominantly apparent throughout the phase of the tourism activities and events and sometimes afterward.

Tourism as a recognized enterprise is still to be enhanced by the Local Government of Lanuza. Their objective is to create more diverse tourist activities to help local people's financial autonomy and increase government revenue. The Local Government's tourism plan is not yet evident, but they have shown interest in ecotourism, which, if decided, should benefit both the community and the environment. The local people are stakeholders in tourism development. Thus, local communities' involvement is vital in attaining ecological and socio-economic sustainability. They should be involved in the policy and project design because they are in direct contact and the first to see the changes and transformations in their community based on the outcomes of tourism growth. The local communities' involvement in tourism development is vital for attaining ecological and socioeconomic sustainability, particularly the marginalized. The residents of tourist destinations are stakeholders in tourism development. Their perception of tourism development has a significant impact on tourism growth in their community. Sustainable tourism development is profoundly reliant on local people's goodwill, support, perception, and participation in tourism-related activities and programs (Jaafar, Ismail, \& Rasoolimanesh, 2015; Liu et al., 2012).

The support of tourism among residents an essential factor for tourism development; residents influence tourist satisfaction and are the key to achieve sustainability. As a result, if the government wants to be effective in any tourism project, they must first recognize and consider the factors that affect the host community's support. Subjective indicators are vital signs for Public Administrators. It is a critical control mechanism on the administration side because it allows the formulation of corrective actions of any negative effect tourism brings. Furthermore, it represents citizens' perceptions of the government, which is essential because residents are the administration's internal clients. The United Nations World Tourism Organization (UNWTO) has indicated that residents' evaluations of the various impacts of tourism, as well as their happiness, are critical for tourism's long-term viability. Tourists have been turned off by the hostility of the local people in severe cases. Suppose the goal of the local government is sustainable tourism. In that case, they must recognize the positive return on investment needed to attract suitable tourism activity for the tourism destination (Sanchez del Rio-Vazquez, Rodriguez-Rad, \& Revilla-Camacho, 2019; UNWTO, n.d.).

Tourists generate economic benefits such as employment, and problems due to the environmental harm it can cause and affect the community's socio-cultural spheres. In connection, these indicators are not only economic and socio-cultural. Environmental aspects of tourism development should be considered a critical strategic variable that allows political actors to gauge and understand the impacts of tourism on the destination. It is important to place equal emphasis and importance on tourism development, highlighting the economic and the socio-cultural, and environmental effects (Sanchez del Rio-Vazquez et al., 2019). In terms of tourism growth, under the objectives of (UNWTO, n.d.) The environmental, economic, and socio-cultural values of tourism growth are all addressed by sustainability concepts. A satisfactory balance must be struck between these three aspects or values to 
ensure long-term viability. Public administrators' aim should not only be focused on the revenue side of tourism but also to determine its effects on the community. Thus, the direction should be increasing the positive effects and reducing or diminish the negative effects of tourism.

This research can help the Local Government Unit in Lanuza understand the Doot Poktoy's residents' economic, social, and environmental values and concerns. The study's results can assist the Local Government in Lanuza in creating a sustainable plan and enhance tourism activities aligned to sustainable mission, strategies, and operation. Although several published works on the effects of tourism based on the residents' perception exist, a comparison of its positive and negative effects was not found. The study desires to bridge the gap and determine if the residents' responses have a disparity. Specifically, the study's objectives are the following: (a) Determine the positive and negative effects of tourism based on the residents' perception; and b) Test the significant difference between the residents' response in their perception of the positive and negative effects of tourism.

\section{METHODOLOGY}

The respondents in this study are the registered adult residents of the surfing area of Doot Poktoy, Lanuza Surigao del Sur. The Slovin's test was done, and the formula was set at a $95 \%$ confidence level and a margin of error at 0.5 . This established the 93 sample population size of eligible residents. Furthermore, the study's respondents must have the following qualification: (a) the respondent has to be at least 18 years of age, and (b) has been a resident of Lanuza for at least 10 years.

This study is a descriptive type of research that used a survey instrument. The questions were based on the impacts of tourism by Cruz (2005, pp. 1-33), which restated the positive and negative effects of tourism on its economic, socio-cultural and environmental values. Then the summarized statements were streamlined to suit the respondents. The questionnaires were translated from English to the Surigaonon language. To discover the residents' perception of the positive and negative effects of tourism. The statements in the questionnaire applied a Likert scale level of agreement response anchor with a calculation of .79 interval. The following response scale anchor designates 5 as strongly agree, 4 as in agree, 3 neither agree or disagree, 2 as in disagree, and 1 as strongly disagree. Before the study's proper conduct, written consent was attained from the Barangay Captain of Zone 1.

\section{RESULTS AND DISCUSSION}

The study was able to garner responses from 39.78\% male and $60.21 \%$ female respondents, with distinct educational attainment from high school graduate which is the largest group representation at $29.03 \%$, followed by high school level at $22.58 \%$, college level at $19.35 \%$; college graduate at $13.97 \%$; elementary graduate at $10.75 \%$ and the elementary level as the smallest representation among the respondents at $4.30 \%$. 
Table 1. Itemized results on the Positive Effects of Tourism

\begin{tabular}{|c|c|c|}
\hline \multicolumn{3}{|l|}{ Positive Effects of Tourism } \\
\hline & Mean & $\begin{array}{c}\text { Verbal } \\
\text { Description }\end{array}$ \\
\hline \multicolumn{3}{|l|}{ Economic } \\
\hline 1. Tourism in Doot Poktoy has brought employment opportunities. & 3.24 & $\begin{array}{l}\text { Neither Agree or } \\
\text { Disagree }\end{array}$ \\
\hline $\begin{array}{l}\text { 2. Tourism in Doot Poktoy has increased small business } \\
\text { opportunities. }\end{array}$ & 4.10 & Agree \\
\hline 3. Infrastructure in Lanuza has been developed due to tourism. & 3.40 & Agree \\
\hline Economic weighted mean & 3.58 & Agree \\
\hline \multicolumn{3}{|l|}{ Socio-Cultural } \\
\hline $\begin{array}{l}\text { 1. I am able to gain knowledge and new culture from tourists in } \\
\text { Lanuza. }\end{array}$ & 4.03 & Agree \\
\hline 2. Tourism has aided in promoting our local culture. & 3.09 & $\begin{array}{l}\text { Neither Agree or } \\
\text { Disagree }\end{array}$ \\
\hline $\begin{array}{l}\text { 3. Tourism has strengthened the cultivation of our cultural pride and } \\
\text { sense of identity. }\end{array}$ & 3.77 & Agree \\
\hline $\begin{array}{l}\text { 4. The preservation and restoration of cultural heritage have been } \\
\text { realized because of tourism. }\end{array}$ & 4.04 & Agree \\
\hline Socio-Cultural weighted mean & 3.73 & Agree \\
\hline \multicolumn{3}{|l|}{ Environmental } \\
\hline $\begin{array}{l}\text { 1. Tourism has led us to understand the fragility and importance of } \\
\text { protecting our environment through the government and partners' } \\
\text { environmental programs. }\end{array}$ & 4.17 & Agree \\
\hline $\begin{array}{l}\text { 2. Tourism has enhanced our environment through ecological } \\
\text { enhancement activities initiated by either government and } \\
\text { stakeholders' projects. }\end{array}$ & 3.71 & Agree \\
\hline $\begin{array}{l}\text { 3. Tourism has contributed to the maintenance of the protection and } \\
\text { conservation of Lanuza's natural resources. }\end{array}$ & 3.62 & Agree \\
\hline Environmental weighted mean & 3.83 & Agree \\
\hline Positive effects of tourism average weighted mean & 3.71 & Agree \\
\hline
\end{tabular}

Table 1 shows the results of the gathered responses from the residents of Doot Poktoy. The mean was calculated, which was necessary to analyze the data collected. This indicates that in the set of tourism positive effects, the environmental values attained the highest mean of 3.83, which translated as the residents agree in the manifestation of the positive environmental effects of tourism in Lanuza. The statement under that category, "Tourism has led us to understand the fragility and importance of protecting our environment through the government and partners' environmental programs." has garnered the highest rate. Next, is the socio-cultural value, which obtained a 3.73 mean translated as the residents agreeing to the positive socio-cultural effects of tourism Lanuza. The statement "The preservation and restoration of cultural heritage have been realized because of tourism." got the highest mean of 4.04. The economic value attained the lowest among all the values on the positive effects at 3.58 with a verbal translation; the residents agree in the manifestation of the positive economic effects of tourism in Lanuza. The results 
coincide with the studies of Andrés Marques, Ribeiro Candeias, \& Rebelo de Magalhães (2020); Butarbutar \& Soemarno (2013); Sunlu (2003); Zaei \& Zaei (2013). Tourism can vitally result in the environmental conservation, protection, and maintenance of the natural resources and use it sustainably. Besides this, tourism is an economic sector that significantly contributes to economic progress, substantially improves the labor market, and creates work opportunities. Tourism also helps decrease poverty due to the characteristics of its activities provides employment and business opportunities-likewise, tourism results in enriched socio-cultural components.

Table 2. Itemized results on the Negative Effects of Tourism

\begin{tabular}{|c|c|c|}
\hline \multicolumn{3}{|c|}{ Negative Effects of Tourism } \\
\hline & Mean & Verbal Description \\
\hline \multicolumn{3}{|l|}{ Economic } \\
\hline $\begin{array}{l}\text { 1. The occurrence of tourism in Lanuza has increased } \\
\text { the prices of goods and other commodities. }\end{array}$ & 4.31 & Strongly Agree \\
\hline $\begin{array}{l}\text { 2. The manifestation of tourism in Lanuza has caused } \\
\text { an increase in land values, especially in Doot Poktoy. }\end{array}$ & 4.30 & Strongly Agree \\
\hline $\begin{array}{l}\text { 3. The work available in the field of tourism and } \\
\text { hospitality is mostly affected by seasonality. }\end{array}$ & 4.44 & Strongly Agree \\
\hline Economic weighted mean & 4.35 & Strongly Agree \\
\hline \multicolumn{3}{|l|}{ Socio-Cultural } \\
\hline $\begin{array}{l}1 \text { The existence of tourism in Lanuza has commodified } \\
\text { the local culture of the residents. }\end{array}$ & 3.17 & Neither Agree or Disagree \\
\hline $\begin{array}{l}\text { 2. Tourist growth in Doot Poktoy has led to the loss of } \\
\text { land of native residents. }\end{array}$ & 3.52 & Agree \\
\hline $\begin{array}{l}\text { 3. The residents in Doot Poktoy have acquired many } \\
\text { new traits and behaviors that may result in our } \\
\text { culture's disappearance. }\end{array}$ & 3.87 & Agree \\
\hline $\begin{array}{l}\text { 4. Tourism in Lanuza has amplified the rate of crime } \\
\text { such as prostitution and drug use. }\end{array}$ & 4.35 & Strongly Agree \\
\hline Socio-Cultural weighted mean & 3.72 & Agree \\
\hline \multicolumn{3}{|l|}{ Environmental } \\
\hline $\begin{array}{l}\text { 1. There have been tourist sites that have been } \\
\text { maltreated by tourists and inappropriately developed } \\
\text { as tourist destinations. }\end{array}$ & 3.09 & Neither Agree or Disagree \\
\hline $\begin{array}{l}\text { 2. The tourist sites in Lanuza are suffering from } \\
\text { pollution such as overcrowding. }\end{array}$ & 3.38 & Neither Agree or Disagree \\
\hline $\begin{array}{l}\text { 3. Tourist development in Doot Poktoy has led to the } \\
\text { loss of the natural habitat of wildlife. }\end{array}$ & 3.44 & Agree \\
\hline Environmental weighted mean & 3.30 & Neither Agree or Disagree \\
\hline Negative effects average weighted mean & 3.78 & Agree \\
\hline
\end{tabular}

Table 2 shows that only the statements under the economic value respondents strongly agree on the manifestation of the negative economic effects of tourism. The statement that garnered the highest rating under the environmental aspect "The work available in tourism is mostly affected by seasonality." Next is the sociocultural value attained a mean of 3.72. Specifically, the statement "Tourism in Lanuza has amplified in the rate of crime such as prostitution and drug use." obtained the highest mean at 4.35 , which is the highest of any statement under the 
positive and negative effects. The result can be likened to Jaafar et al., (2015), the presence of varied positive and negative socio-cultural impacts of tourism, including the cultural damage increases in drug prostitution crimes. In this study, the last among the criteria of negative effects is the environmental value attaining a 3.30 weighted mean. Respondents neither agree nor disagree with the demonstration of the negative environmental effects of tourism in Lanuza.

Incorrect tourism development practices can result in negative social effects on the tourist destination. It is the local community that sees this firsthand, such as transformations in their lifestyles. In connection, the significance of the preservation of traditional cultures has various social and economic benefits. The loss of traditions in the local communities in the face of "advancement" can be a disadvantage since tourists also want a local cultural experience. Instead of losing these traditions, they should be preserved and be promoted. Tourism development can generate substantial impacts that cause primary concern to local communities (Chang, Chien, Cheng, \& Chen, 2018; Jaafar et al., 2015; Matsuoka \& Kelly, 1988; Puri, 2019; Shahzalal, 2016). The concept of economic benefits of tourism entails that the local community has to be much better with tourism than without it. The clear advantages that have to be scrutinized include the deliberation of the costs of tourism growth and the opportunity costs of tourism-related activities. Academic and experimental studies propose that although tourism has a positive impact on economic development, it is also responsible for its unfavorable effects on the environment and the host community's lives. Tourism can cause substantial environmental damage. A sustainable form of tourism is important because it values the economic, socio-cultural, and environmental facets of tourism equally. In most developing countries, the monetary value is the only consideration. They disregard the socio-cultural and environmental importance (Marius \& Luisa, 2016; Mikayilov et al., 2019).

Ardahaey (2011) stated that some communities, especially underprivileged ones, depend too much on tourism. There are several negative economic effects of tourism, such as highly seasonal work due to the tourism industry's nature, the lower standard wage of tourism associated industries, the obstruction and surges in prices of products, and land values. It is crucial to have an understanding of the complexity of tourism. In connection, this will result in identifying the adverse outcomes before the progression of the tourism industry. In lessening the negative effects from any tourism activities, It is fundamental to anticipate the negative impacts, do relevant cooperation between stakeholders, empower local communities, improve the community, and protect the future. Tourism can operate well if sustained by all stakeholders. The successful efforts in diminishing the negative effects of tourism can be achieved if there is good harmonization among all parties concerned and avoid any conflict of interests among sectors (Butarbutar \& Soemarno, 2013; Liu et al., 2012).

A Sign test is used to evaluate the difference between the positive and negative answers of the respondents. This non-parametric test was used since the study's data satisfy all the statistical tools' assumptions. 
Table 3. The significant difference between the positive and negative responses of the residents on their perception of tourism in Lanuza using the Sign test

\begin{tabular}{ll}
\hline & Positive- Negative \\
\hline $\mathrm{Z}$ & -8.247 \\
\hline Asymp. Sig. (2-tailed) & .000 \\
\hline
\end{tabular}

a. $\quad$ Sign test

Based on the results of 93 respondents who were asked to evaluate tourism's effects, their responses were tested to uncover if there was a significant difference between the resident's perception of the positive and negative effects of tourism. An exact sign test was used to compare the differences. The negative tourism effect has a statistically significant mean compared to the positive tourism effect, $p=.000$.

According to Rua (2020), Understanding how locals view tourism can help to facilitate more positive tourism planning and management decisions. These manifestations can be interpreted as evidence of shifting perception toward tourism, raising why this is happening, especially if the perceptions become negative. The higher the positive perception, the more constructive outcomes than the adverse consequences being dealt with the residents, which should be ideal for a tourism destination. However, the higher the negative effects means that residents are experiencing more harmful consequences of tourism.

Regardless of whether the findings are positive or negative, Policymakers and other tourism stakeholders should improve the negatives and strengthen the positives. The manifestations of the positive and negative effects of tourism have an element in the overall situation of the community how tourism as an activity in the destination changed and affected the community. Tourism developers should be working to increase public support for tourism because it is necessary for long-term growth. The support for tourism should be based on a balanced assessment of the activity's benefits and costs (Rua, 2020).

Despite the disparities in the residents' responses to both positive and negative effects, the answers may vary based on the residents' subjective viewpoints. The financial benefit of tourism and each participant's comprehension of tourism can influence their point of view. This research is beneficial in gaining a better understanding of the residents' analyses on tourism impacts. Because of the nature of this study, there are inevitable limitations. Future research may expand the sample size and branch out into new areas to better reflect the overall population. More comprehensive data may reveal more diverse effects and patterns. Since this study's concentration is in Doot Poktoy, Lanuza, the results can be applied to other tourism destinations. A qualitative approach to the impact of tourism may be explored in future studies. It is hoped that this study will serve as a staging post for new research into issues relating to how locals perceive tourism as a whole.

\section{CONCLUSION}

The residents of Doot Poktoy have found an apparent manifestation of both positive and negative effects in all the tourism values: economic, socio-cultural, and environmental. However, the residents have a higher negative perception of tourism 
than a positive one. Residents are experiencing the undesirable impacts of tourism more than the positive. They are somehow conscious of both the positive and negative effects of tourism. The indications of tourism's positive and negative effects are a part of the community's overall condition and how tourism as an economic activity transformed and altered society. Policymakers and other tourism stakeholders should take action on improving the negative effects and emphasize the positive effects. The manifestations of tourism's positive and negative effects play a role in the community's overall condition and how tourism as a destination transformed the community. It is essential to include the contribution and support of the locals in tourism development, harmonizing the facets of economic, sociocultural, and environmental values for the tourism destination's success.

\section{REFERENCES}

Andrés Marques, M. I., Ribeiro Candeias, M. T., \& Rebelo de Magalhães, C. M. (2020). How Residentes Perceive the Impacts of Tourism. The Case of the Historic Centre of Porto. International Journal of Management Science and Business Administration, 6(6), 7-14. https://doi.org/10.18775/ijmsba.18495664-5419.2014.66.1001

Ardahaey, F. T. (2011). Economic impacts of tourism industry. International Journal of Business and Management, 6(8), 206-215. https://doi.org/10.5539/ijbm.v6n8p206

Butarbutar, R., \& Soemarno, S. (2013). Environmental effects of ecotourism in Indonesia. Journal of Indonesian Tourism and Development Studies, 1(3), 97107. https://doi.org/10.21776/ub.jitode.2013.001.03.01

Chang, K. G., Chien, H., Cheng, H., \& Chen, H. (2018). The impacts of tourism development in rural indigenous destinations: An investigation of the local residents' perception using Choice Modeling. Sustainability, 10(12), 4766. https://doi.org/10.3390/su10124766

Cruz, Z. (2005). Principles of Tourism II. Quezon, Philippines: Rex Bookstore Inc.

Jaafar, M., Ismail, S., \& Rasoolimanesh, S. M. (2015). Perceived social effects of tourism development: A case study of Kinabalu National Park. Theoretical and Empirical Researches in Urban Management, 10(2), 5-20. Retrieved from fromhttps://www.jstor.org/stable/24873524?refreqid=excelsior\%3A4d914b3f 88f845a18ee8e088f7771ad4\&seq=1\#metadata_info_tab_contents

Khan, A., Bibi, S., Lorenzo, A., Lyu, J., \& Babar, Z. U. (2020). Tourism and development in developing economies: A policy implication perspective. Sustainability, 12(4), 1618. https://doi.org/10.3390/su12041618

Liu, W., Vogt, C. A., Luo, J., He, G., Frank, K. A., \& Liu, J. (2012). Drivers and socioeconomic impacts of tourism participation in protected areas. PloS One, 7(4), e35420. https://doi.org/10.1371/journal.pone.0035420 
Manila Standard. (2017). Lanuza town is Mindanao's new surfing destination. Manila Standard. Retrieved November 21, 2020, from https:/manilastandard.net/lgu/mindanao/251820/lanuza-town-is-mindanao-snew-surfing-destination-.html

Marius, M., \& Luisa, V. (2016). Economic effects of tourism and its influencing factors: An overview focusing on the spending determinants of visitors. Zeitschrift Für Tourismuswissenschaft, $8(2), \quad$ 169-198. https://doi.org/10.1515/tw-2016-0017

Mason, P. (2003). Tourism Impacts, Planning and Management. London: Butterworth Heinemann.

Matsuoka, J., \& Kelly, T. (1988). The environmental, economic, and social impacts of resort development and tourism on native Hawaiians. He Journal of Sociology \& Social Welfare, 15(4). Retrieved from https://scholarworks.wmich.edu/jssw/vol15/iss4/3

Mikayilov, J. I., Mukhtarov, S., Mammadov, J., \& Azizov, M. (2019). Re-evaluating the environmental impacts of tourism: does EKC exist? Environmental Science and Pollution Research, 26(19), 19389-19402.

Pramanik, P. D., \& Ingkadijaya, R. (2018). The impact of tourism on village society and its environmental. IOP Conference Series: Earth and Environmental Science, 145(1), 12060. IOP Publishing. https://doi.org/10.1088/1755$1315 / 145 / 1 / 012060$

Puri, J. (2019). Socio-Economic Impacts of Wildlife Tourism in Kasara, Chitwan. Journal of APF Command and Staff College, 2(1), 70-79. https://doi.org/10.3126/japfcsc.v2i1.26746

Rua, S. V. (2020). Perceptions of tourism: a study of residents' attitudes towards tourism in the city of Girona. Journal of Tourism Analysis: Revista de Análisis Turístico. https://doi.org/10.1108/jta-03-2019-0015

Sanchez del Rio-Vazquez, M.-E., Rodriguez-Rad, C. J., \& Revilla-Camacho, M.A. (2019). Relevance of social, economic, and environmental impacts on residents' satisfaction with the public administration of tourism. Sustainability, 11(22), 6380. https://doi.org/10.3390/su11226380

Shahzalal, M. (2016). Positive and Negative Impacts of Tourism on Culture: A Critical Review of Examples from the Contemporary Literature. Journal of Tourism, Hospitality and Sports, 20, 30-35. Retrieved from https://iiste.org/Journals/index.php/JTHS/article/view/31719

Spilanis, I., Vayanni, H., \& Glyptou, K. (2013). Evaluating the tourism activity in a destination: the case of Samos Island. Études Caribéennes, (23). https://doi.org/10.4000/etudescaribeennes.6257

Sunlu, U. (2003). Environmental impacts of tourism. Conference on the 
Relationships between Global Trades and Local Resources in the Mediterranean Region, 263-270. Retrieved from https://om.ciheam.org/article.php?IDPDF=4001977

UNWTO. (n.d.). Sustainable development. Retrieved from https://www.unwto.org/Sustainable-Development

Zaei, M. E., \& Zaei, M. E. (2013). The impacts of tourism industry on host community. European Journal of Tourism Hospitality and Research, 1(2), 12 - 21. Retrieved from https://www.eajournals.org/journals/european-journalof-hospitality-and-tourism-research-ejhtr/vol-1-issue-2-september2013/impacts-tourism-industry-host-community/ 